\begin{tabular}{|c|c|c|}
\hline institute & $\begin{array}{l}\text { CARADDE: Jurnal Pengabdian Kepada Masyarakat } \\
\text { https://journal.ilininstitute.com/index.php/caradde } \\
\text { Volume 2 | Nomor 2 | Februari |2020 } \\
\text { e-ISSN: } 2621-7910 \text { dan p-ISSN: 2621-7961 } \\
\text { DOI: https://doi.org/10.31960/caradde.v2i1.264 }\end{array}$ & $\begin{array}{l}\text { IUIN } \\
\text { CARADDE }\end{array}$ \\
\hline
\end{tabular}

\title{
Upaya Pemberantasan Buta Aksara Melalui Pelatihan Membaca Menulis Berhitung (CALISTUNG) di Kampung Pendidikan
}

\section{Nur Hafsah Yunus MS, Andriani, Nurhidayah}

\author{
Keywords : \\ Buta Aksara; \\ Membaca; \\ Menulis; \\ Berhitung;
}

\section{Corespondensi Author}

Program Studi Pendidikan Bahsa Indonesia, Universitas Al Asyariah Mandar, Sulawesi Barat, Indonesia.

Email: hafsahnur.iswaka@yahoo.co.id

\section{History Artikel}

Received: 14-Agustus-2019; Reviewed: 13-Oktober-2019; Accepted: 30-oktober-2019; Avalaible Online: 04-November 2019; Published: 04-Februari-2020;

\begin{abstract}
Abstrak. Tujuan pelatihan membaca, menulis, dan berhitung (Calistung) adalah untuk meningkatkan kualitas Sumber Daya Manusia, mengurangi tingkat kebodohan yang merupakan sumber dari kemiskinan. Diharapkan dengan adanya pelatihan membaca, menulis, dan berhitung (Calistung) dapat meningkatkan taraf hidup masyarakat dengan saling memahami yang dikerjakan baik tulisan maupun fakta lisan. Metode yang digunakan adalah melalui pendekatan kepada warga buta aksara dengan menggunakan metode alpabet. Dengan demikian, Kelompok Kampung Pendidikan Desa Kuajang Kecamatan Binuang Kabupaten Polewali Mandar memiliki akses untuk memperoleh pengetahuan dibidang teknologi dan informasi. Hasil yang diperoleh dalam kegiatan ini adalah terjadinya peningkatan kemampuan membaca, menulis, dan berhitung masyarakat Desa Kuajang sebagai salah salah satu bentuk upaya pemberantasan buta aksara pada masyarakat Desa Kuajang Kecamatan Binuang Kabupaten Polewali Mandar.
\end{abstract}

\section{PENDAHULUAN}

Desa Kuajang adalah merupakan sebuah desa kecil yang merupakan salah satu Desa dari 9 Desa dan 1 Kelurahan di wilayah Kecamatan Binuang Kabupaten Polewali Mandar. Dengan luas wilayah 5,40 km, Desa Kuajang adalah pemekaran dari Kelurahan Induk yang berada di sebelah selatan desa ini yaitu Kelurahan Tonyaman. Setelah memekarkan diri, desa ini berstatus Kelurahan Persiapan Kuajang (Tahun 1994), dengan lurah pertamanya yaitu Muhammad Ilyas. Kelurahan persiapan Kuajang akhirnya berubah lagi statusnya menjadi Desa Definitif yaitu Desa Kuajang (Tahun 2002). Hal ini berdasarkan Peraturan Daerah Nomor 5 Tahun 2002 seiring dengan berlakunya otonomi daerah dengan kepala desa pertamanya yaitu Hasanuddin,S.Pd.I.

Kondisi sosial masyarakat Desa Kuajang masih kental dengan adat istiadat seperti dalam sistem kekerabatan masih terdapat strata sosial misalnya: Tomakaka (orang yang dituakan), dan gelar Puang (Keturunan Raja),hal tersebut sejalan dengan konsep ketahanan masyarakat sehingga sifat Gotong Royong masih sangat melekat di hati masyarakat serta persatuan dan kesatuan masih tetap terjaga hingga saat ini. 
Secara administratif Desa kuajang mempunyai daerah dengan luas wilayah 5.40 $\mathrm{km} 2$, secara keseluruhan 1.200 ha yang terbagi atas Tanah sawah, tanah kering (Pemukiman dan Ladang), Tanah perkebunan, Tanah Fasilitas Umum dan Tanah Hutan. Desa Kuajang terdiri dari 5 (Lima) dusun atau lingkungan yaitu dusun Lemo Tua, dusun Lemo Baru, dusun Sarampu I, dusun Sarampu II, dan Dusun Pakkandoang berdasar pada Data Biro Pusat Statistik Kabupaten Polewali Mandar (2018) berpenduduk 2.824 jiwa dengan jumlah 700 kepala keluarga.

Berdasarkan analisis situasi tersebut, permasalahan yang dihadapi mitra, antara lain: (1) belum mengenalkan huruf dan angka; (2) belum dapat membaca huruf alfabet dan angka dengan baik dan benar; (3) belum dapat menghitung matematika dasar.

Calistung adalah singkatan dari membaca, menulis, dan berhitung. Calistung merupakan tahapan dasar orang bisa mengenal huruf dan angka. Banyak pakar yang menganggap bahwa calistung penting untuk mempermudah komunikasi dalam bentuk bahasa tulis dan angka. Umumnya belajar calistung ini banyak disampaikan di pendidikan formal, yaitu sekolah. Fenomena muncul ketika ada masyarakat belum bisa mengenyam sekolah. Mereka tahu hurufhuruf dan angka, tetapi tidak bisa membaca. Mereka tahu uang, tetapi tidak bisa menghitung. Tahap-tahap pengenalan inilah yang mulai banyak dikaji dan dikembangkan dalam pengembangan metode calistung atau literasi.

Menurut Rudell dalam Marrow (66:1993) mendefinisikan membaca sebagai salah satu dari penggunaan berbahasa untuk menguraikan tulisan atau simbol dan memahaminya. Dijelaskan juga Tampubolon bahwa membaca merupakan kegiatan fisik dan mental untuk menemukan makna dan tulisan. Menurut Bond dalam Abdurrahman (200:2003) membaca merupakan pengenalan simbol-simbol bahasa tulis yang merupakan stimulus yang membantu proses mengingat tentang apa yang dibaca untuk membangun suatu pengertian melalui pengalaman yang telah dimiliki. Sedangkan Aulina (134: 2012) menyatakan bahwa membaca bukan hanya sekadar melafalkan huruf-huruf atau kata demi kata, namun lebih dari itu membaca merupakan proses menkonstruksi yangh melibatkan banyak hal, baik aktivitas fisik, berpikir, psikolinguistik, dan metakognitif. Membaca mencakup aktivitas proses penerjemahan tanda dan lambing-lambang ke dalam maknanya, pengenalan kata, pemahaman literal, interpretasi dan pemahaman makna bacaan, dan mengaitkan pengalaman pembaca dengan teks yang dibaca. Jadi membaca merupakan suatu kegiatan yang dilakukan untuk mengenali simbol-simbol serta makna yang terkandung dalam bahasa tulis dengan tujuan untuk mendapatkan informasi.

Tujuan utama dari membaca adalah agar seseorang dapat mengenal tulisan serta mampu memaknai isi dari tulisan yang dibaca. Adapun factor-fator yang mempengaruhi perkembangan membaca seseorang disebabkan oleh kemampuan guru, lingkungan, latar belakang social, serta fasilitas yang tidak memadai.

Kreatifitas menulis merupakan suatu bentuk manifestasi kemampuan dan keterampilan berbahasa yang paling akhir dikuasai oleh pembelajar bahasasetelah kemampuan mendengarkan, berbicara, dan membaca. Bila dibandingkan dengan tiga kemampuan yang lai, kamampuan menulis lebih sulit dikuasai bahkan oleh penutur asli bahasa yang bersangkuta sekalipun. Hal ini disebabkan kemampuan menulis menghendaki penguasaan berbagai unsur kebahasaan dan unsur di luar bahasa itu sendiri yang akan menjadi isi tulisan baik unsur bahasa maupun unsur isi haruslah terjalin sedemikian rupa sehingga menghasilkan tulisan yang runtut dan padu (Iskandar Wassid dan Sunendar, 2009:248).

Menurut Suparno $(2008,13)$, menulis merupakan suatu keterampilan berbahasa yang digunakan untuk berkomunikasi secara tidak langsunng atau tidak secara tatap muka. Selain iitu, menurut Sujanto (1998:56), ,emulis merupakansuatu keterampilan berbahasa yang dilandasi dengan pengetahuan kebahasaan baik tentang kaidah-kaidah kebahasaan. Jasi dapat disimpulkan bahwa menulis merupakan suatu penyampaian pesan (komunikasi) dengan menggunakan bahasa tulis sbagai medianya.

Berhitung adalah kegiatan yang dilakukan seseorang untuk mengembangkan kemamouan menyusun bilangan. Pengembangannya dimulai dari lingkungan 
yang terdekat, sejalan dengan pengembangan kemampuan seseorang dapat meningkat ke tahap pengertian mengenai jumlah, yaitu berhubungan dengan penjumlahan dan pengurangan (Susanto, 2011:98). Pentingnya mempelajari dan menguasai teknik berhitung karena berhitung dapat membantu seseorang untuk menguasai dan memecahkan masalahmasalah yang ada dalam kehidupan seharihari.

Berhitung sangat penting dalam kehidupan sehari-hari dan mempunyai banyak tujuan (Sujiono, 2007:98), diataranya adalah: 1) sesorang dapat berpikir logis dan sistematis sjk dini, melalui pengamatan terhadap bendabenda konkret, gambar-gambar atau angkaangka yang terdapat di lingkungan sekitar, 2) dapat menyesuaikan dan melibatkan diri dalam kehidupan bermasyarakat yang dalam kesehariannya memerlukan keterampilan berhitung, 3) memiliki ketelitian, konsentrasi, abstrak, dan daya apresiasi yang tinggi, 4) memiliki pemahaman konsep ruang dan waktu serta dapat memperkirakan kemungkinan urutan suatu peristiwa yang terjadi di lingkugan sekitar, 5) memiliki kreatifitas dan imajinasi dalam menciptakan sesuatu secara spontan.

Berhitung juga memiliki manfaat yang sangat besar (Montolalu, 2005;1.19), adapun manfaat berhitung adalah: 1) mengoptimalkan fungsi otak, 2) melatih daya imajinasi dan kreativitas, logika, sistematika berpikir, daya konsentrasi dan daya ingat, 3) meningkatkan kecepatan, ketepatan, dan ketelitian dalam berpikir, 4) menumbuhkan rasa percaya diri dan sikap mental positif,, terutama dalam menghadapi soal-soal berhitung.

Berdasarkan hasil observasi dan survei kepada Kepala Desa Kuajang, masih banyak penduduk yang tidak tamat sekolah dasar. Padahal pendidikan merupakan salah satu aspek penting dalam kehidupan serta diakui sebagai kebutuhan pokok manusia secara keseluruhan. Semakin tinggi tingkat pendidikan masyarakat, semakin baik pula kualitas sumber dayanya. Diakui atau tidak, dunia pendidikan ini terus menimbun berbagai permasalahan. Meski telah berganti aparat birokrat dan orde pemerintahan serta banyaknya kampanye tentang pentingnya pendidikan,, dunia pendidikan tak kunjung lepas dari sejumlah permasalahan klasik baik menyangkut kualitas, daya jangkau masyarakat terhadap pendidikan, budi pekerja para siswa minimnya pendidikan yang disediakan pemerintah, hingga minat belajar para siswa. Sektor pendidikan merupakan sektor yang dominan dalam pembangunan Sumber Daya Manusia (SDM). Hal ini terlihat dari beberapa indikator yang terkait dengan pembangunan SDM atau kualitas hidup penduduk yang selalu memasukkan komponen pendidikan dalam penentuan penghitungannya. Salah satu indikator yang biasa digunakan diantaranya tingkat pendidikan yang ditamatkan, angka melek huruf dan angka buta huruf/buta aksara. Menurut Biro Pusat Statistik (BPS), buta aksara di Indonesia pada tahun 2010 masih sebesar $10 \%$ dari jumlah penduduka Indonesia atau sekitar 23.751.617 jiwa penderta buta aksara usia lebih dari 15 tahun

Upaya pemberantasan buta aksara pada Desa Kuajang khususnya yang menjadi mitra perlu mendapat perhatian serius. Meningkatkan pengetahuan masyarakat khususnya kelompok mitra dalam melakukan metode pelatihan Calistung secara berkesenambungan dan jangka panjang dapat menjadi cara tepat untuk mengurangi jumlah angka buta aksara bahkan memberantas buta aksara tersebut. Kegunaaan pelatihan calistung bagi warga buta aksara antara lain: (1) meningkatkan kualitas Sumber Daya Manusia, mengurangi kebodohan yang merupakan sumber kemiskinan; (2) meningkatkan taraf hidup masyarakat dengan saling memahami yang dikerjakan baik tulisan maupun fakta lisan; dan (3) akses untuk memperoleh pengetahuan di bidang teknologi dan informasi.

\section{METODE}

Metode pendekatan Pelatihan Calistung di Desa Kuajang Kecamatan Binuang adalah pendekatan kepada warga buta aksara. Peneliti memperoleh data peserta calistung dari Kepala Desa Kuajang.

Adapun tahapan pelaksanaan pelatihan calistung di Desa Kuajang Kecamatan Binuang Kabupaten Polewali Mandar, antara lain: (1) Tahap Persiapan: pendataan calon peserta buta aksara Desa Kuajang, persetujuan kerjasama pelatihan calistung antara peneliti dengan kelompok pemuda kampung pendidikan sebagai mitra, persiapan media, sarana, dan prasaran pembelajaran; (2) 
Tahap pelatihan: tes awal, pelatihan; (3) Tahap ujian: ujian dilakukan dengan metode undian kalimat (diambil, ditulis, dan dibaca), dikte (mendikte dan meminta peserta menulis secarik kertas), dan undian hitungan (diambil, dihitung, dievaluasi hasilnya;

Tahap suvervisi (monitoring dan evaluasi pelaksanaan program); dilaksanakan dengan cara mengadakan tes membaca, menulis, dan berhitung. Instrumen pelaksanaan pelatihan adalah kartu pintar, modul, buku latihan, kancing baju, dan uang (Aminatun, 2008).

Berikut merupakan indikator keberhasilan dari kegiatan pelatihan calistung: Tabel 1: Indikator evaluasi produk

\section{HASIL DAN PEMBAHASAN}

Kegiatan Pelatihan Calistung ini dilaksanakan selama 1 minggu yakni pada tanggal 7 April 2019 sampai dengan 14 April 2019. Namun sebelum melaksanakan pelatihan membaca, menulis, dan berhitung ini terlebih dahulu dilakukan pendataan berkaitan dengan warga Desa Kuajang yang tergolong Buta Aksara baik anak-anak, remaja, maupun kalangan dewasa. Hasil pendataan diperoleh 35 warga Desa yang belum mampu membaca, menulis, dan berhitung.

Kegiatan Pelatihan ini diawali dengan pemberian pretest terhadap kemampuan membaca, menulis, dan berhitung peserta. Kemudian dilanjutkan dengan pelaksanaan pelatihan membaca, menulis, dan berhitung secara bertahap.

Kegiatan pelatihan membaca dilaksanakan memberikan pengenalan mengenai huruf kapital dan huruf kecil kepada peserta, kemudian dilanjutkan dengan memberika pelatihan membaca dengan cara mengeja huruf dalam satu kata. Langkah berikutnya dilanjutkan dengan melatih peserta membaca kalimat, dan dilanjutkan dengan membaca beberapa kalimat dalam paragraf.

Selain itu, kegiatan pelatihan menulis juga dilaksanakan dengan membagikan alat tulis berupa buku, pensil, dan penghapus kepada peserta. Kegiatan pelatihan menulis ini di awali dengan memberikan pelatihan cara menuliskan semua huruf baik huruf kapital maupun huruf kecil. Setelah melihat kemajuan kemampuan peserta untuk menuliskan huruf, kegiatan dilanjutkan dengan memberikan latihan kepada peserta untuk menuliskan kata yang terdiri dari beberapa huruf. Para peserta diberikan pula penjelasan mengenai aturan dalam menulis dan penggunaan tanda baca.

Kegiatan dilanjutkan dengan memberikan pelatihan berhitung, pelatihan berhitung ini diawali dengan memberikan penjelasan pengenalan angka mulai dari angka satuan, puluhan, ribuan, dan seterusnya. Selain itu, dalam pelatihan ini dijelaskan pula perbedaan antara angka dan bilangan., bahwa bilangan merupakan konsep dan angka merupakan lambang bilanganya. Dalam pelatihan ini dijelaskan pula mengenai pengenalan operasi penjumlahan, pengurangan, perkalian, pembagian, serta simbol dari keempat operasi tersebut. Penjelasan mengenai berhitung ini juga mengangkat masalah yang berkaitan dengan kehidupan sehari-hari sehingga peserta dapat dengan mudah memahami dan memecahkan masalah yang diberikan. Selain itu, dalam kegiatan ini dipraktekkan pula kegiatan berhitung dengan menggunakan jarimatika.

Kegiatan pelatihan membaca, menulis, dan berhitung ini menitikberatkan pada proses mengaktifkan peserta untuk mempraktekkan kegiatan membaca, menulis, dan berhitung sehingga memberikan pengalaman belajar kepada peserta agar materi yang diberikan dapat dipahami dengan baik. Sebagai bentuk evaluasi dari keberhasilan kegaiatan ini adalah dengan memberikan postest kepada peserta untuk mengetahui kemampuan membaca, menulis, dan berhitung masyarakat Desa Kuajang setelah menerima materi yang diberikan.

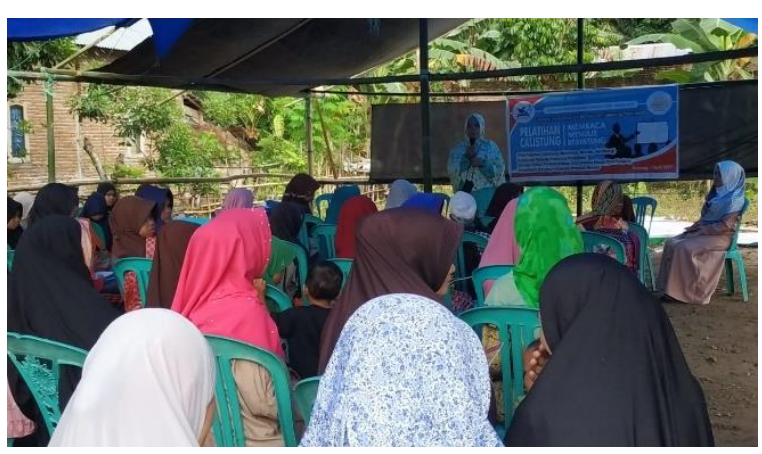

Gambar 1. Peneliti sedang menyampaikan materi 


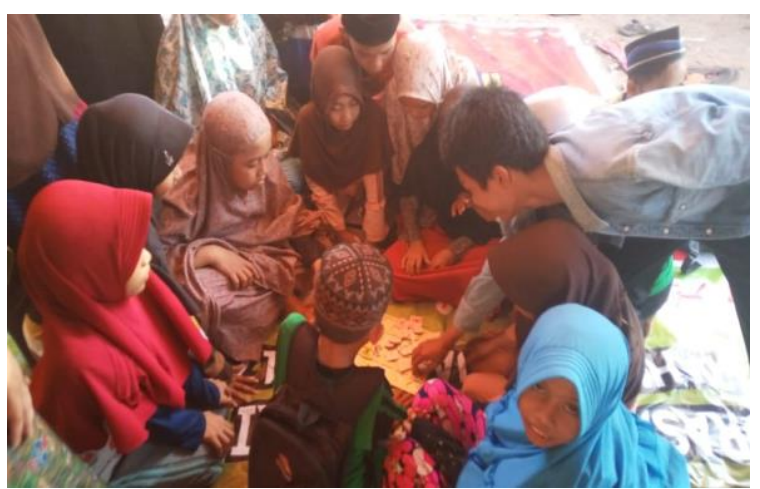

Gambar 2. Peserta antusias menyelesaikan menyusun kata dengan menggunakan alat peraga

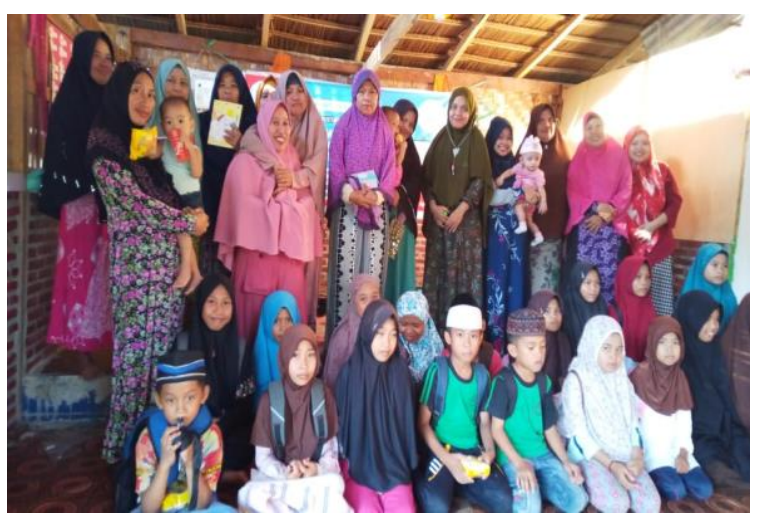

Gambar 3. Peserta dan pemateri (peneliti)

Hasil kemampuan membaca peserta dari hasil pretest diperoleh dari 35 orang peserta diperoleh 15 orang peserta atau sekitar $42,86 \%$ yang benar-benar belum bisa mengenal huruf secara keseluruhan, 20 orang atau sekitar $57,14 \%$ peserta yang telah mengetahui sebagian huruf baik huruf kapital maupun huruf kecil, dan tidak ada peserta yang mengetahui huruf kapital maupun huruf kecil secara keseluruhan, serta tidak ada pula peserta yang mampu membaca dengan benar. Sedangkan hasil postest menunjukkan bahwa setelah mengikuti pelatihan membaca diperoleh 35 orang peserta atau $100 \%$ peserta dapat mengenal huruf baik huruf kapital maupun huruf kecil, 25 orang atau $71,43 \%$ telah mampu membaca dengan benar meskipun dengan mengeja, serta sekitar 10 orang atau $28,57 \%$ yang mampu membaca dengan lancar semua kata dalam kalimat. Hal ini menunjukkan peningkatan yang signifikan kemampuan membaca sebelum dan setelah pelaksanaan pelatihan membaca di Desa Kuajang.

Hasil penelitian yang relevan dengan penelitian ini adalah penelitian yang dilakukan oleh Atrianing Yessi dan Wijayanti (2016) yang berjudul Pelatihan Calistung pada Buta Aksara Warga Dusun Setro menunjukkan bahwa terjadi peningkatan $90 \%$ kemamuan calistung masyarakat setelah melalui pelatihan.

Penelitian kedua oleh Rina Yulianti dan Rahmawati (2002) yang berjudul Pelatihan Calistung bagi Perempuan Pesisir sebagai Upaya Pemberantasan Buta Aksara di Desa Banten Kecmatan Kasemen. menunjukkan bahwa pelatihan calistung bagi perempuan di Desa Banten Kecamatan Kasemen berjalan dengan sangat lancar. Para warga sangat antusias dan termotivasi untuk belajar walaupun setelah itu, mereka harus membantu suami yang pulang melaut.

Sementara itu, hasil pelatihan calistung yang kami dapatkan adalah kemampuan menulis peserta dari hasil pretest diperoleh dari 35 orang peserta diperoleh 23 orang peserta atau sekitar $65,71 \%$ yang belum mengetahui cara menulis baik huruf kapital maupun huruf kecil, selain itu sebanyak 12 orang peserta atau sekitar 34,29\% peserta yang mengetahui cara menulis sebagaian huruf baik huruf kapital maupun huruf kecil, dan tidak ada peserta yang mengetahui cara menulis huruf secara keseluruhan baik huruf kapital maupun huruf kecil. Sedangkan hasil postest menunjukkan bahwa dari 35 orang peserta atau sekitar $100 \%$ peserta mampu menulis dengan benar huruf kapital maupun huruf kecil secara keseluruhan, sebanyak 26 orang atau $74,29 \%$ peserta mampu menulis huruf dalam satu kata, serta sebanyak 9 orang atau 25,71 peserta yang telah mampu menuliskan huruf yang dirangkai dalam kata dalam satu kalimat. Hal ini menunjukkan bahwa terjadi peningkatan kemampuan peserta dalam menulis setalah mengikuti pelatihan menulis di Desa Kuajang.

Hasil kemampuan berhitung peserta berdasarkan hasil pretest diperoleh bahwa dari 35 orang peserta diperoleh bahwa tidak ada peserta yang belum mengetahui angka secara keseluruhan, sebanyak 18 orang atau sekitar $51,43 \%$ yang telah mengetahui angka namun belum mampu berhitung, serta sebanyak 17 orang atau $48,57 \%$ peserta yang telah mengetahui angka dan mampu berhitung dengan operasi penjumlahan (tidak mengetahui operasi pengurangan). Sedangkan dari hasil postest diperoleh bahwa sebanyak 30 orang atau $85,71 \%$ peserta yang mampu mengenal angka dan berhitung sebagian operasi, dan sebanyak 5 orang atau 14,29\% 
Caradde: Jurnal Pengabdian Kepada Masyarakat

Vol 2 No 2, Februari 2020

peserta yang mampu mengenal angka, behitung operasi dengan penjumlahan, pengurangan, perkalian, maupun pembagian. Hal ini menunjukkan bahwa terjadi peningkatan kemampuan berhitung peserta setelah pelatihan berhitung yang dilakukan di Desa Kuajang Kacamatan Binuang Kabupaten Polewali Mandar.

\section{SIMPULAN DAN SARAN}

Hasil dari kegiatan pelatihan membaca, menulis, dan berhitung (calistung) yaitu terjadinya peningkatan kemampuan masyarakat Desa Kuajang dalam hal membaca, menulis, dan berhitung, hal ini terbukti sebagai salah satu uapaya dalam memberantas buta aksara masyarakat Desa Kuajang khususnya dan masyarakat Polewali Mandar pada umumnya.

Saran setelah pelatihan Calistung ini adalah pengembangan terkait kegiatan pemberantasan buta aksara melalui pelatihan membaca. menulis, dan berhitung (calistung) ini sangat diperlukan untuk dijadikan program tahunan sebagai satu upaya pembarantasan buta aksara, yang diaharapkan dapat dilakukan secara merata ke daerah-daerah yang memiliki angka buta aksara yang cukup tinggi. Keaktifan pemuda dalam kegiatan ini perlu ditingkatkan agar setelah pelatihan, kegiatan belajar bersama tetap berlanjut.

\section{DAFTAR RUJUKAN}

Abdurrahman, Mulyono. 2003. Pendidikan bagi Anak Berkesulitan Belajar. Jakarta: Rineka Cipta.

Aminatun, S. 2008. Pemanfaatan Monograf dan Batang Napier sebagai Media Pembelajaran Berhitung Matematika Dasar. Jurnal Pendidikan Inovatif Volume 3, Nomor 2 Maret 2008.

Aulina, Choirun Nisak. 2012. Pengaruh Permainan dan Penguasaan Kosakata terhadap Kemampuan Membaca Permulaan Anak Usia 5-6 Tahun. Jurnal Pedagogia.

Biro Pusat Statistik (2018). Polewali Mandar dalam Angka 2018. BPS. Polewali.
Badan Pusat Statistik Jakarta Pusat. 2010. Statistik Indonesia Tahun 2010. Jakarta Pusat: Badan Pusat Statistik.

Iskandar, W, Dadang S. 2009. Strategi Pembelajaran Bahasa. Bandung: Remaja Rosdakarya.

Atrianing Yessi dan Wijayanti.2016. Pelatihan Calistung pada Buta Aksara Warga Dusun Setro. E-DIMAS.Volume 07 No. $01 \quad$ Maret 2016. http://journal.upgris.ac.id/index.ph $\mathrm{p} / \mathrm{e}$-dimas/article/view/1035

Rina Yulianti dan Rahmawati. 2002. Pelatihan Calistung bagi Perempuan Pesisir sebagai Upaya Pemberantasan Buta Aksara di Desa Banten Kecmatan Kasemen.Jurnal Perempuan Volume 3 No.23 Tahun 2002.

http://150.107.142.250/index.php/j lppm/article/viewFile/190/121.

Marrow, Lesley Mandel. 1993. Literacy Development in the Early Years. United AState of America: Allyn and Bacon.

Montolalu, B.E.F. dkk. 2005. Bermain dan Permainan Anak. Jakarta: Universitas Terbuka.

Sujiono, Yuliani, Nurani. 2009. Konsep Dasar Pendidikan Anak Usia Dini. Jakarta: Indeks.

Suparno,, M. Yunus. 2006. Keterampilan Dasar Menulis. Jakarta : Universitas Terbuka.

Susanto, Ahmad. 2011. Perkembangan Anak Usia Dini Pengantar dalam Berbagai Aspeknya. Jakarta: Kencana.

Suyanto. 1988. Pedoman Pelaksanaan Penelitian Tindakan Kelas (PTK). Yogyakarta: Dirjen Dikti Dikbud.

Tampubolon. Mengembangkan Minat dan Kebiasaan Membaca pada Anak. Bandung: Angkasa. 